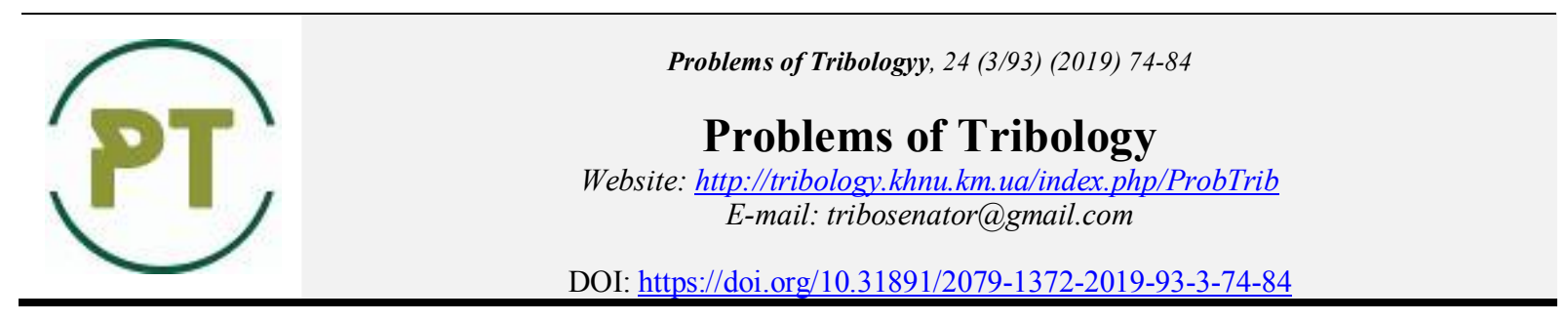

\title{
Increase of wear resistance of cast iron by the directed of structure formation of his matrix with vermicular graphite
}

\author{
V. Aulin*, V. Kropivnyi, O. Kuzyk, V. Kropivna \\ Central Ukrainian National Technical University, c. Kropyvnytskyi, Ukraine \\ EE-mail: AulinVV@gmail.com
}

\begin{abstract}
The study was made of cast iron with vermicular graphite of the mark CIVG 300-4, for the production of which it was used the melts with a composition close to the eutectic, modified with the VL 63 (M) TS lag containing $\mathrm{Mg}=6.5 \%, \mathrm{Ca}=1.8 \%, \mathrm{Si}=46 \%, \mathrm{RZM}=0.7 \%, \mathrm{Fe}$ - the rest. The results of the influence on the structure of the metal matrix, modification conditions and formation of vermicular graphite are given. Perlite areas located between eutectic colonies of vermicular graphite as the place of formation of phosphide inclusions and micropores are revealed. It is determined that increase in dispersion of inclusions of vermicular graphite leads to a decrease in mechanical properties by reducing the compactness of graphite inclusions and increasing the ferritization of the metal base. Influence of residual magnesium content in different structures of graphite is given. The influence of the thickness of the cross-section of casting on the content of perlite in the structure of the metal matrix of cast iron with vermicular graphite, the change of its structure with acceleration of cooling of casting and the character of the distribution of $\mathrm{Si}, \mathrm{Mn}, \mathrm{Cr}$ and $\mathrm{P}$ are studied. It has been found that the use of antimony as a perlizator complicates its strong deglobuliratory action, and chrome by bleaching effect. It has been determined that microleagulation by chromium provides only up to $60 \ldots 65 \%$ perlities, and the addition of $0.3 \%$ copper can increase the perlite content up to $80 \%$. It has been shown that despite the higher degree of perlization, the hardness of pig iron with vermicular graphite with microleagulation by antimony in all cross sections is lower than with microleagulation by chromium. At the same time, the reduction of the microhardness of perlite by the addition of antimony can be a promising method of providing increased wear resistance of cast by the iron with vermicular graphite.
\end{abstract}

Key words: vermicular graphite, microalloying, perlizating, wear resistance.

\section{Introduction}

One of the most promising among these materials is cast iron with vermicular graphite (CIVG). A large amount of scientific research is directed at the study of this material. In comparison with grey iron, cast iron with vermicular graphite has a higher strength and increased plasticity. In comparison with pig iron spherical graphite CIVG has several advantages: lower coefficient of thermal expansion, higher thermal conductivity, higher stability when working under conditions of thermo cyclic loads, better damping properties, higher level of casting properties. This complex of properties determines the possibility of efficient use of CIVG for the manufacture of brake discs of high-speed rail transport, blocks and head of cylinders of powerful internal combustion engines, exhaust manifolds.

Technological techniques (micro alloying, heat treatment) allow to make castings with CIVG with different content of perlite according to their setting. So, for the manufacture of exhaust manifolds to prevent high-temperature growth ferrite CIVG is used. Blocks and cylinder heads are made mainly of perlite CIVG, which provides maximum strength with high thermo physical characteristics. For ordinary castings in machine building, CIVG with a ferrite-pearlitic matrix is widely used.

\section{Literature Review}

The machine-building industry is a stable consumer of cast iron castings. In 2016, the total volume of 
their production was close to 80 million tons [1]. At the same time, the potential of cast iron as a material is still not fully realized. The production of grey cast iron with flaked graphite almost twice exceeds the production of high-strength pig-iron. In addition, the use of CIVG allows you to reduce the mass of powerful diesel engines up to $22 \%$ [2].

In Ukraine, the grades of CIVG are regulated by DSTU 3926-99, which defines four grades of CIVG: CIVG 300-4, CIVG 300-5, CIVG 400-4, CIVG 500-1, where the first group of numbers is the time resistance of tensile rupture, $\mathrm{MPa}$; second digit - relative elongation, \%. The iron is first and foremost determined by the ratio of the content of ferrite and perlite in the structure of the metal matrix. With an increase in the content of perlite by $20 \%$ (from 60 to $80 \%$ perlite), an increase in the tensile strength of $10 \ldots 15 \%$ and a decrease in relative elongation (plasticity) is observed. The content of perlite is also significantly affected by the hardness and wear resistance of CIVG.

The production of CIVG expands the use of "Inmold" - the process, the essence of which is the processing of iron-silicon melts - magnesium ligatures inside the casting form [3]. The technology of modification inside the casting form (MICF) is characterized by high efficiency and special thermo-kinetic conditions of modifying treatment of the melt. As a result of such processing, the time between the introduction of the additive and the crystallization of the melt is reduced, more dispersed structures are formed, there is no need for secondary forming graphitizing modification. The structure of CIVG produced by MICF is quantitatively different from the structure of pig iron obtained by traditional methods of ladle modification.

\section{Purpose of the study}

The purpose of this study is to increase of wear resistance of cast iron by the establishment the peculiarities of the formation of CIVG, obtained by modifying the inside of the casting mold, and developing ways of controlling the formation of the metal base during the eutectoid transform.

\section{Research Methodology}

High-strength cast iron was smelted in an induction stove, the chemical composition of which corresponded to the mark CIVG 300-4 (DSTU 3926-99). Melt materials with a composition close to eutectic $(3.1 \ldots 3.9 \% \mathrm{C}$ and $1.6 \ldots 2.9 \% \mathrm{Si}$ ) were used to obtain $\mathrm{CIVG}$, which provides high casting properties. The decrease of the carbon equivalent resulted in an increase in the inclination of the cast-iron to crystallization with a whiteness, and the transition to zeevtectic compositions causes the formation of point graphite, which leads to a decrease in the level of mechanical properties. The melting was carried out on a charge, which included casting cold and natural-alloyed pig-iron, the return from the production of high-strength pig-iron and ferroalloys, which ensured the production of melts with a sulfur content of less than $0.03 \%$. Qualitative results were obtained with the application of steel scrap after carburization with an electrode fight. The melt was modified with VL 63 (M) TS with a content of $\mathrm{Mg}=6.5 \%, \mathrm{Ca}=1.8 \%, \mathrm{Si}=46 \%, \mathrm{REM}=0.7 \%, \mathrm{Fe}$ - the rest. Before modification, the ligation was additionally ground and sifted, using a fraction of $1.5 \ldots 4.0 \mathrm{~mm}$ for treatment.

The research was carried out by comparing the results of MICF and ladle modification. In both cases, experimental castings, consisting of a step-by-step sample for conducting metallographic research, a blank for the determination and testing of mechanical and two discontinuous samples with a diameter of the bursting section of $16 \mathrm{~mm}$, used in mechanically untreated for accelerated control of mechanical properties.

The experimental pilot casting system included a reaction chamber in the form of a cut cone with a ratio of the main dimensions established on the basis of recommendations for the acquisition of pig iron with spherical graphite by in-line modification [4]. To improve the interaction of the melt with the ligature, the tangential delivery of the metal into the reaction chamber was carried out.

It was found that the creation in the reaction chamber of the mode of the centrifugal movement accelerates the formation of a rigid-solid medium, which contributes to the intense dissolution of the modifier. In comparison with rectangular reaction chambers, when modifying in a centrifugal reaction chamber with a modifier consumption of $1 \%$ of the weight of the poured metal, the residual magnesium content in the metal of the casting is increased by 1.5 times.

The main parameter that determines the kinetics of dissolution of the ligature in the melt with MICF is the dissolution factor $(F R)$ :

$$
F R=V / S
$$

where $V$ - speed of pouring of metal into the form, $\mathrm{kg} / \mathrm{of} \mathrm{c}$;

$S$ - area of the horizontal intersection of the reaction chamber, $\mathrm{m}^{2}$.

The dissolution factor determines the amount of ligature that is absorbed by the melt when modified inside the casting mold and is regulated by changing the melt pouring rate into the shape and size of the reaction chamber. The design of the model equipment of the experimental casting allowed the use of variable reaction 
chambers with a diameter $D_{1}$ in the range of $30 \ldots 60 \mathrm{~mm}$ and thereby change the dissolution factor within $100 \ldots 700 \mathrm{~kg} / \mathrm{s} \times \mathrm{m}^{2}$.

To study the influence of the cooling rate on the formation of pig-iron, an installation was developed that allows to increase the cooling rate of individual areas of casting in the temperature range of the eutectoid transform (Fig. 1).
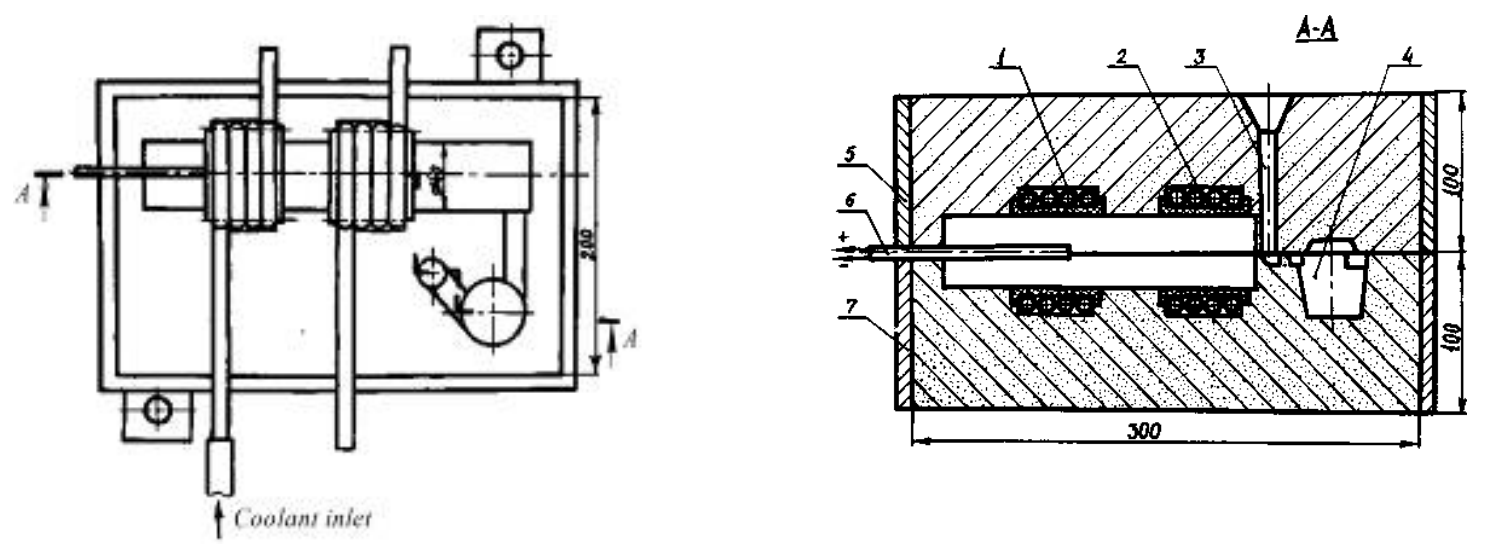

Fig. 1. Design of the installation for studying the effect of cooling rate on the formation of pig iron:

$$
\begin{gathered}
1 \text { - a cooling block; } \\
2 \text { - a control block; } \\
3 \text { - a chimney; } \\
4 \text { a reactionary chamber; } \\
5 \text { - overhead casting box; } \\
6 \text { - a thermocouple; } \\
7 \text { - lower casting box }
\end{gathered}
$$

Inside the foundry there were cooling blocks in the form of a spiral from a $5 \mathrm{~mm}$ diameter steel tube with a refractory coating. In the center of the cavity of the foundry formed by the inner surface of the cooling unit, a thermocouple is installed, the electromotive force of which is registered by an automatic potentiometer. At a given temperature in the process of cooling through the cooling unit flow of flowing water was provided, which provided 4 times the acceleration of cooling of this casting area. To determine the independent influence of the cooling unit on the formation of the structure of the casting, a control block was inserted into the mold, through which the water was not passed through the cooling process. Gypsum was prepared according to the generally accepted technique. The metallographic analysis was performed using a microscope REM-106.

\section{Results}

When constructing iron castings, as well as developing a technology for their mechanical processing, it is important to know the structure of the metal matrix, as well as the effect on its formation of modification conditions. CIVG obtained by MICF according to the applied technology differs from the lower content of $\mathrm{Mg}_{\text {res }}$ obtained with scoop retrofitting by a greater dispersion of graphite inclusions, as well as a lower tendency to crystallize with a whitening effect that affects the structure of the metal matrix. The formation of vermicular graphite is accompanied by an abnormal ferritization of a metal matrix. In the structure of the metal matrix of CIVG, obtained by MICF and CIVG, obtained by ladle modification, perlite areas are located between eutectic colonies of VG and are places of arrangement of phosphide inclusions and micropores (Fig. 2)

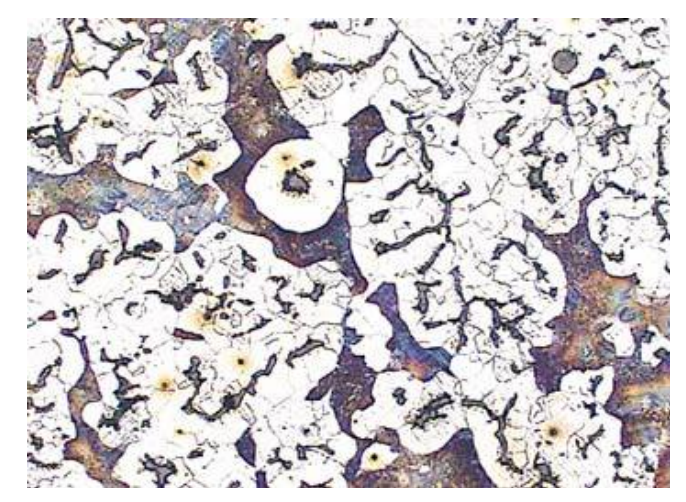

Fig. 2. Microstructure CIVG $3 \mathrm{Mg}_{\text {res }}=\mathbf{0 , 0 1 5} \%$ (crossing of 35 мм thick after MICF, x100 
The increase in the structure of high-strength pig-iron dispersion inclusions of vermicular graphite from VGf3 to VGf1 (GOST 3443-87) leads to a decrease in mechanical properties as a result of reducing the compactness of graphite inclusions and by increasing the ferritization of the metal base. Ferrites are noticeably thicker around inclusions of vermicular graphite compared with spherical graphite. Formation of inclusions of vermicular graphite is accompanied by abnormal ferritization [5] (Fig. 3, b No.5). An explanation of such an effect can be made on the basis of the determination of the method of stereometric metallography for a certain increase in the length of the section of the section "graphite-metal matrix", which provides a reduction of carbon pathways in the process of eutectoid transformation (Fig. 3, b No.4).

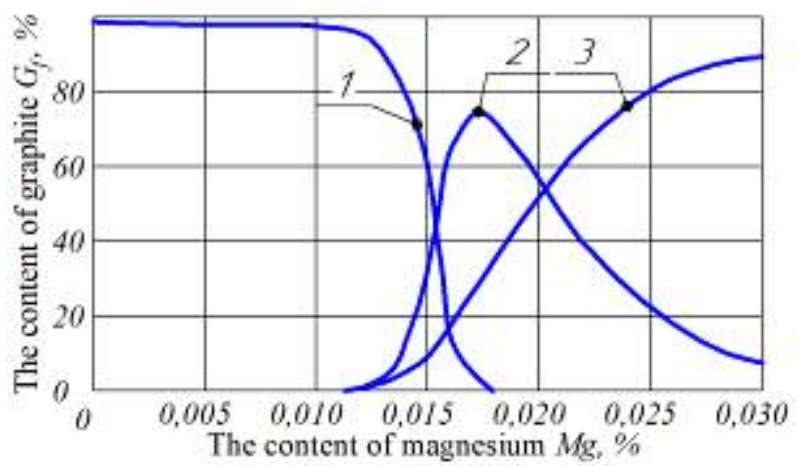

a

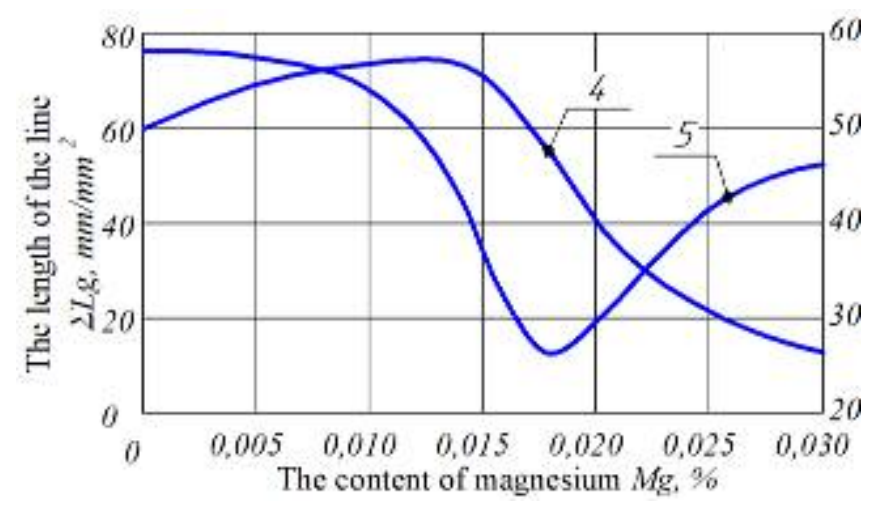

b

Fig. 3. Influence of the residual magnesium content in pig-iron, obtained by modification in the casting on: a - the ratio of graphite inclusions in the structure of cast iron;

b - the length of the line of the section "graphite-metal matrix" and the content of perlite;

1 - plate graphite;

2 - vermicular graphite;

3 - spherical graphite;

4 - the length of the line of the section;

5 - the content of perlite;

In-process [6] the results of the research are presented using the method of X-ray microtomography of the size, shape and distribution of the sizes of graphite inclusions, the distance between its adjacent inclusions in various types of pig iron of the close chemical composition. It was established that the surface area of spheroid graphite inclusions in high-strength cast iron was $0.973 \mathrm{~mm}^{2}$, in CIVG $-2,195 \mathrm{~mm}^{2}$, in gray iron with lamellar graphite $-3.863 \mathrm{~mm}^{2}$. In this case, gray cast iron was characterized by the highest content of perlite in the metal base. Thus, the spatial branching of the inclusions of vermicular graphite can not be recognized as the main cause of abnormal ferritinization of CIVG.

A certain influence on the structure of the metal matrix CIVG is carried out by the thickness of the intersection of the casting, the modification method, as well as the content of Si and Mn, similarly to the effect of these factors in gray and high-strength pig-iron. CIVG, obtained by MICF in thin sections, casting contains a higher amount of perlite than cast iron after batch processing. The reason for this effect is due to the greater compactness of graphite inclusions in the first case.

With a decrease in the content of silicon from 2.9 to $2.1 \%$, or with an increase in the content of manganese from 0.5 to $0.9 \%$, the content of perlite increases by $15 \ldots 20 \%$. At the same time, the maximum number of perlite in the intersection of a thickness of $35 \mathrm{~mm}$ to $50 \%$ is achieved, which indicates the inadequate management of the structure of the metal matrix of quartz crystals by the change in the content of silicon and manganese. 
Intensification of the cooling of castings with CIVG from 1.6 to $4.5 \mathrm{deg} / \mathrm{s}$ in the post-crystallization period in the temperature range from $980{ }^{\circ} \mathrm{C}$ to $600{ }^{\circ} \mathrm{C}$ contributes to noticeable perlizatsii with an increase in cooling rate of more than $2.3 \mathrm{deg} / \mathrm{s}$. At a cooling rate of $4.2 \mathrm{grad} / \mathrm{s}$ content The perlite in the metallic basis is increased by 2.5 times (Fig. 4,5 ).

In this case, the ferrite is invariably placed near the inclusions of vermicular and spheroidal graphite in the form of a curvature, the average thickness of which decreases from 16 to 8 microns with increasing cooling velocity. Thus, effective perlitization of CIVG by increasing the cooling rate in the production environment is possible only in the case of the use of chill casting.

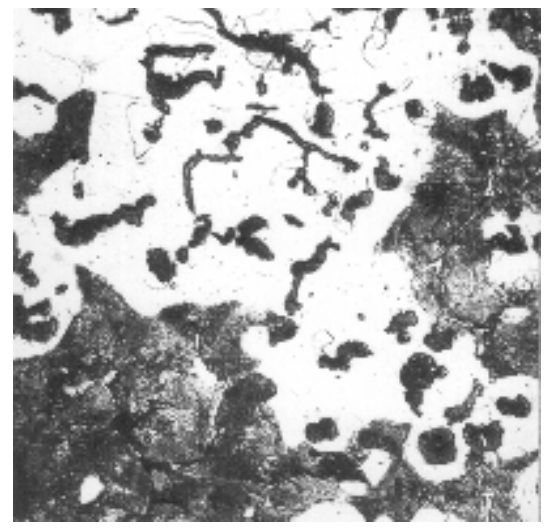

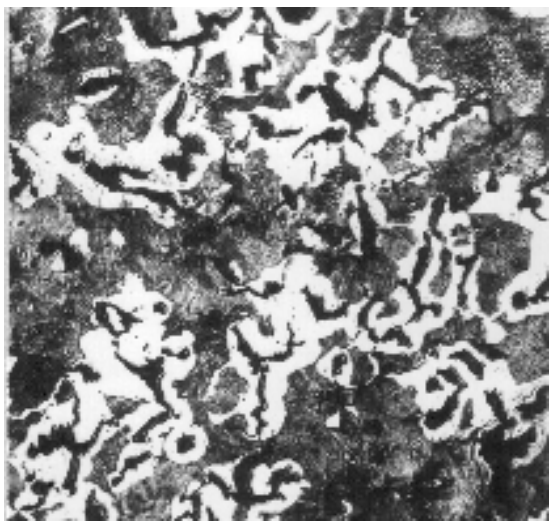

b

Fig. 4. Changing the structure of the metal matrix CHVG when accelerating the cooling of the casting from temperatures $970 \ldots 980{ }^{\circ} \mathrm{C}(\mathrm{x200})$ : a - control casting $(V=1.5 \mathrm{deg} / \mathrm{s})$;

b- accelerated cooling castings $(V=4.2 \mathrm{deg} / \mathrm{s}), \mathrm{x} 200$

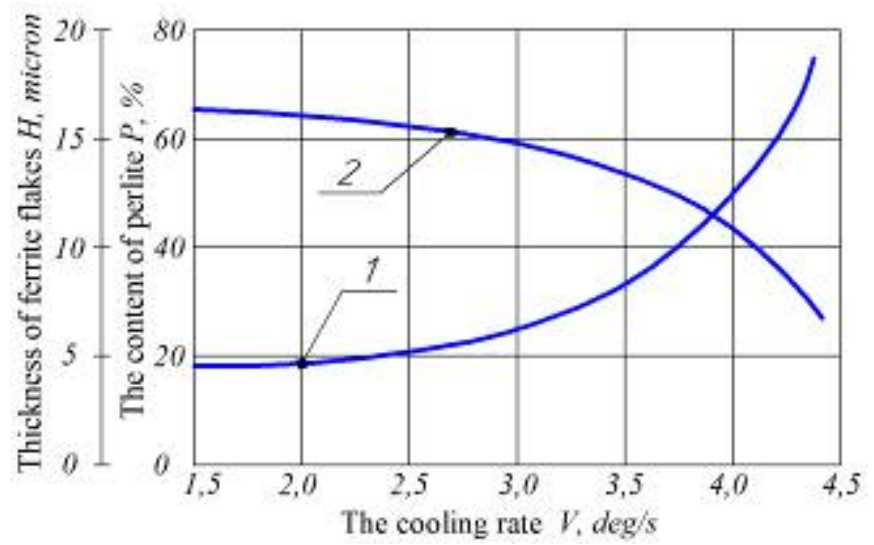

Fig. 5. Influence of the cooling rate in the range of temperatures $980 \ldots 600{ }^{\circ} \mathrm{C}$ on the content of perlite (1) and the average thickness of ferrite flakes near graphite (2)

The evaluation of the effect of the cooling rate on eutectoid transformations in CIVG was carried out by the method of differential thermal analysis [7]. Samples from CIVG after austenisation at $950{ }^{\circ} \mathrm{C}$ were cooled to room temperature at different speeds in the range $1 . . .55 .5^{\circ} \mathrm{C} / \mathrm{min}$. It is confirmed that even at the highest studied cooling rate in the structure of CIVG ferrite grains are found, located predominantly along the inclusions of VG. Such placement of ferrite formation along the particles of VG indicates that the ferrite is formed and grows more easily than inclusions of vermicular graphite in comparison with lamellar and spherical graphite. At the differential cooling curves, at all investigated cooling rates, the thermal peaks of the beginning and end of eutectic transformation are detected. Even at the highest cooling rate there was a small delay associated with the formation of ferrite. An increase in the rate of cooling of samples with CIVG from $1{ }^{\circ} \mathrm{C} / \mathrm{min}$ to $55.5^{\circ} \mathrm{C} / \mathrm{min}$ reduces the temperature of the beginning of eutectoid transformation from $762{ }^{\circ} \mathrm{C}$ to $700{ }^{\circ} \mathrm{C}$, and the completion temperature of perlite formation from $725^{\circ} \mathrm{C}$ to $675^{\circ} \mathrm{C}$

\section{Influence of the distribution of chemical elements in ferrite sections on the properties of CIVG}

Micro-X-ray spectral investigation of microstructure of CIVG showed that the chemical composition of the ferritic sites is characterized by a higher content of $\mathrm{Si}$ and a lower content of $\mathrm{Mn}$ and $\mathrm{Cr}$ (Fig. 6). 


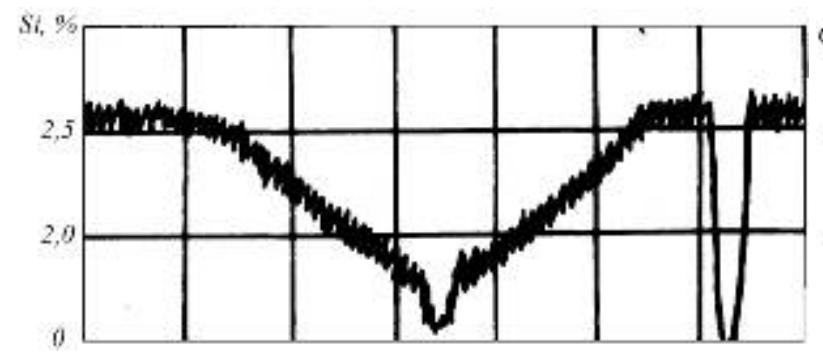

a

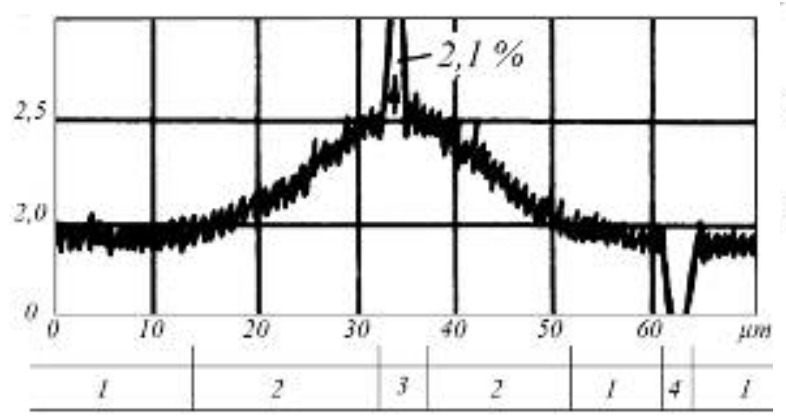

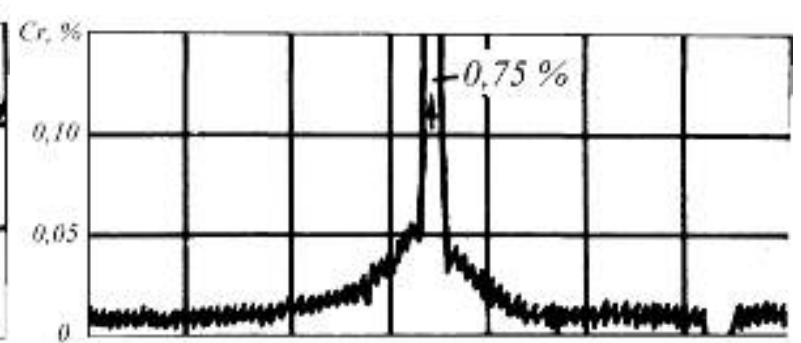

c

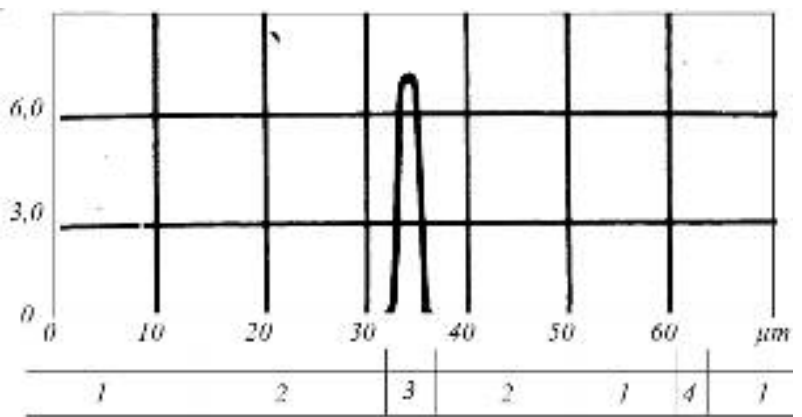

d

Fig. 6. Distribution of Si (a), Mn (b), Cr (c) and $P(d)$ in the metallic matrix of CIVG:

1 - ferrite;

2 - is a pearlite;

3 - including of phosphide;

4 - graphite

Luminous inclusion inside the perlite region is a place of segregation of $\mathrm{P}, \mathrm{Cr}$ and $\mathrm{Mn}$ and is a doped chromium and manganese phosphide. The ferrite is characterized by high homogeneity by $\mathrm{Si}$ and $\mathrm{Mn}$, and at the outlet of the electron probe to the perlite section, the concentration of Si begins to decrease naturally, and Mn begins to grow. Maximum decrease of Si content and increase of Mn in perlite areas occurs near phosphide inclusions. Chrome in the ferrite of the investigated pig iron is practically absent, but in perlite, as far as the distance from ferrite sections, its concentration increases to $0.05 \ldots 0.07 \%$. The character of the distribution of copper, as a pig iron perlitalyst, was similar to silicon, and tin - to chromium.

These results are confirmed by the construction of two-dimensional quantitative pictures of the distribution of $\mathrm{Si}$ and $\mathrm{Mn}$, constructed on the basis of the results of linear microrentense-spectral analysis (Fig. 7). The transition from the ferrite shell around the vermicular and spheroidal graphite to the perlite is associated with a change in the concentration of Si and $\mathrm{Mn}$. The inclusion of vermicular, compact and globular graphite is covered by lines of isoconcentration of $\mathrm{Si}$ and $\mathrm{Mn}$, which are oriented to the position of the surface of the ferrite-vermicular graphite section. The distribution of the $\mathrm{Si}$ and $\mathrm{Mn}$ cast iron structure and the extension of the interface boundary of the graphite-metal matrix from 20 to $25 \mathrm{~mm} / \mathrm{mm}^{2}$ in spheroid graphite to $50 \ldots 60 \mathrm{~mm} /$ $\mathrm{mm}^{2}$ during the formation of a mercuric graphite leads to an increase in the size of sites with high Si content and reduced - Mn.

The statistical processing of the results of the microrentense-spectral analysis shows that the transition from the ferrite to the perlite site, regardless of the degree of compactness of the graphite inclusions, occurs at a content of $3.80 \ldots 3.84 \% \mathrm{Si}$ and $0.63 \ldots 0.64 \% \mathrm{Mn}$. Thus, the formation of a ferrite metal matrix in castings from an uncontrolled CIVG is primarily related to the character of the distribution of silicon and manganese [8].

From the technological point of view, it is promising to reduce the diffusion mobility of carbon atoms by choosing the rational content of $\mathrm{Si}$ and $\mathrm{Mn}$. However, reducing the silicon content will increase the tendency of the melt to crystallize by the metastable mechanism, and increasing the content of manganese by more than $1 \%$ will cause the formation of poly-carbides (Fe-Mn) ${ }_{3} \mathrm{C}$ with increased hardness [9]. The impossibility of obtaining high levels of perlizzation due to changes in the content of permanently present in the cast iron elements necessitates the search for more effective measures of influence on structure formation.

The structure of the metal base of castings is determined by their chemical composition, the cooling rate (thickness of the cross-section), the effectiveness of graphitizing modification, the form of graphite. According to data [10], the coefficient Px, which takes into account the complex perlitizing effect of chemical elements in high-strength castings, is determined from the ratio $\mathrm{Px}=3.0(\% \mathrm{Mn})-2.65(\% \mathrm{Si})+7.75(\% \mathrm{Cu})+90(\% \mathrm{Sn})+$ $+357(\% \mathrm{~Pb})+333(\% \mathrm{Bi})+20.1(\% \mathrm{As})+9.60(\% \mathrm{Cr})+71.7(\% \mathrm{Sb})$. To achieve the same structure of the metal matrix (in terms of perlite content), the copper to the iron should be 8 ... 10 times larger than the addition 
of tin $[10,11]$. Of the aforementioned chemical elements that effectively affect the structure of the metal matrix, there is no resistance to the formation of VG only with the addition of tin, copper, chromium and molybdenum.

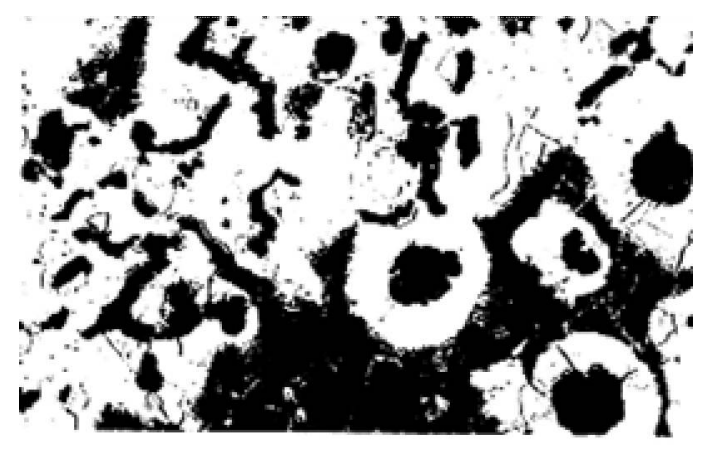

a

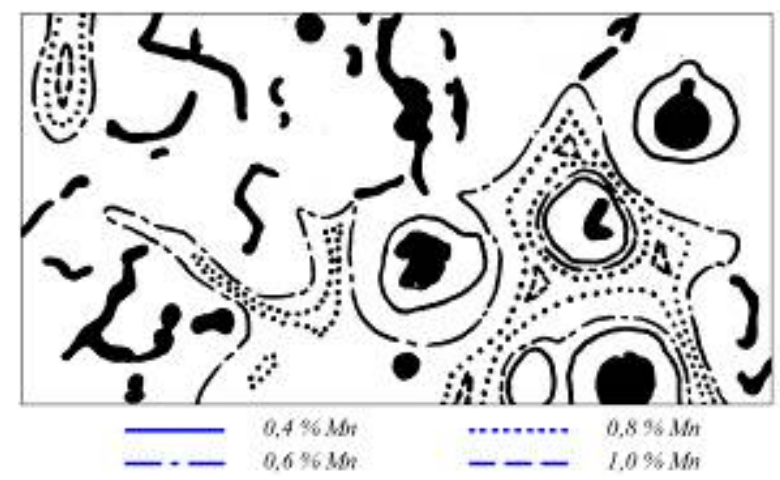

b

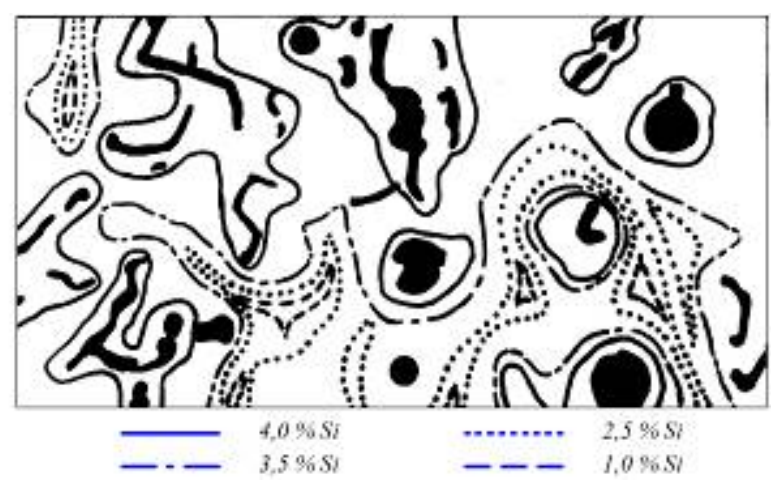

c

Fig. 7. Distribution of Si and Mn in the structure of the metallic matrix of CIVG: a - microstructure of investigated area $(\mathbf{x 2 0 0})$; b - distribution of $\mathrm{Mn}$; c-distribution of $\mathrm{Si}$

The effect of the complex use of minor additives of several alloying elements, as a rule, provides better results than the use of the increased additive of a single alloying element. Copper and tin, as elements that inhibit the formation of ferrite, do not cause the formation of structural-free cementite in thin sections. As a result, there are only slight fluctuations in the structure of the metal matrix of the microlized iron in castings with considerable discrepancy. The study of the effect of copper in an amount up to $3.8 \%$ on the transformation by cooling CIVG modified in the foundry showed [12]:

- copper supplements increase the temperature of the beginning and end of the evacuation transformation at $5 \ldots 8^{\circ} \mathrm{C}$ by $1 \% \mathrm{Cu}$;

- the eutectic conversion temperature decreases with copper supplements by about $5-6^{\circ} \mathrm{C}$ by $1 \% \mathrm{Cu}$;

- copper supplements do not increase the propensity of CIVG to crystallize by metastablemechanism, with an increase in copper content up to $2.0 \%$, there is an increase in the hardness of ferrite and perlite;

- when more than $2.0 \%$ copper is added to the melt, the amount of ferrite in the structure of the metal matrix does not exceed $10 \%$.

The use of such an element as antimony as a perlizator of CIVG is complicated by its strong deglobulirujushchim action, and chromium - a bleaching effect. The low propensity to crystallization with the release of CIVG obtained with MICF, creates the preconditions for the use of microluble chromium, which effectively reduces the carbon diffusion in iron. On the other hand, the maximum reduction of the period between modification and crystallization of the melt with intraformal modification makes it possible to more effectively use antimony for magnesium fermentation in order to perlite.

Chromium was tested in the amount of $0,1 \ldots 0,5 \%$ and $0,01 \ldots 0,05 \%$ antimony in low-sulfur pigments of eutectic composition $(3,5 \ldots 3,6 \% \mathrm{C}, 2,4 \ldots 2,6 \% \mathrm{Si}, 0,60 \ldots 0.65 \% \mathrm{Mn})$, obtained by technology of ladle and intraformal modification. The specified chromium content in the melt was provided with an additive before modification in the ferrochromium bin $\Phi X 015$. In the case of ladle modification in cross sections of a step-bystep test with a thickness of $15 \ldots 35 \mathrm{~mm}$, the increase in chromium content from 0.05 to $0.15 \%$ resulted in an increase in the content of perlite from 25 to $50 \%$ (Fig. 8). 

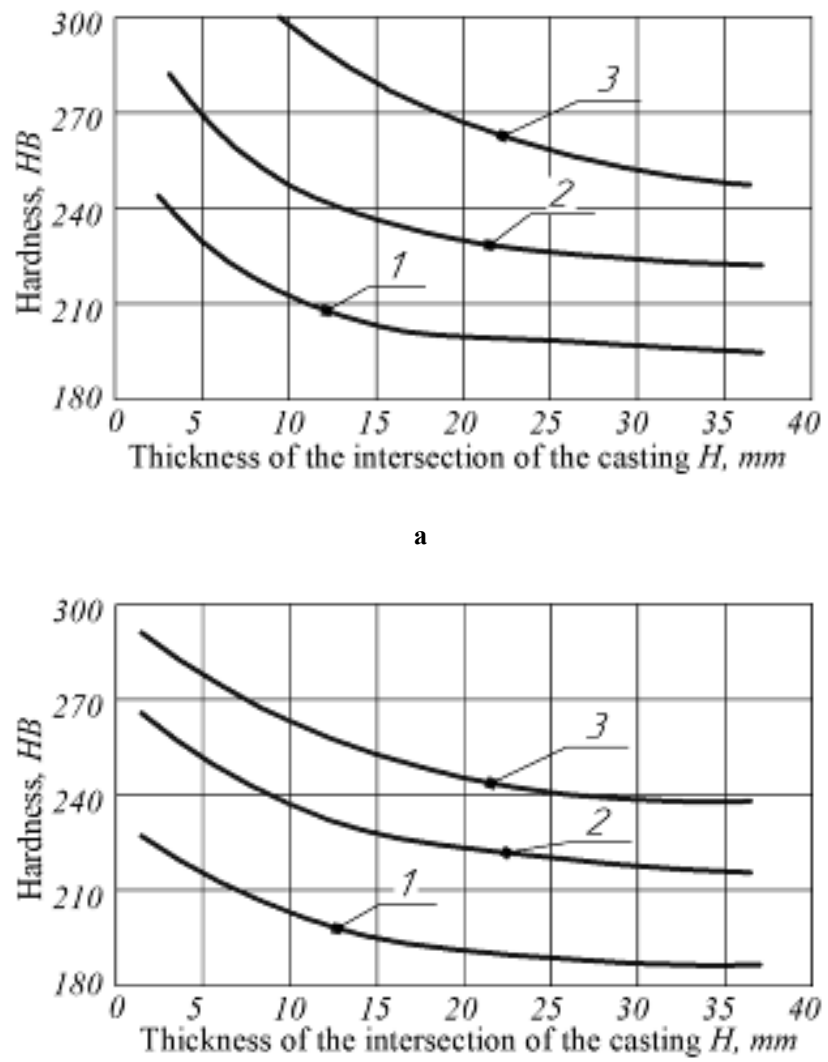

b

Fig. 8. Influence of the thickness of the cross-section of casting on the hardness of CIVG, microlended with chromium: a-ladle modification; b-MICF;

1 - CIVG without micro-alloying additives; 2 - cast iron with $0.15 \% \mathrm{Cr}$;

3 - cast iron with an addition of $0.30 \% \mathrm{Cr}$

With MICF, the more effective graphitizing action of ligatures allows the chromium content to be increased up to $0,3 \%$ in the cast iron without the formation of whitening in the thin sections of the stepped sample and reach in the intersection of a thickness of $35 \mathrm{~mm}$ to $65 \%$ perlite. Along with the perlitration of a metal matrix, chromium as a part of CIVG leads to an increase in the thickness of casting on hardness.

Microglamping chromium CIVG produced by the MICF method provides for a mere 60 to $65 \%$ perlitration and can be used predominantly in the production of thick-walled castings. An additional microleakage of the melt with the addition of $0,3 \%$ copper allowed to increase the content of perlite in the metal base to $80 \%$ (Fig. 9).

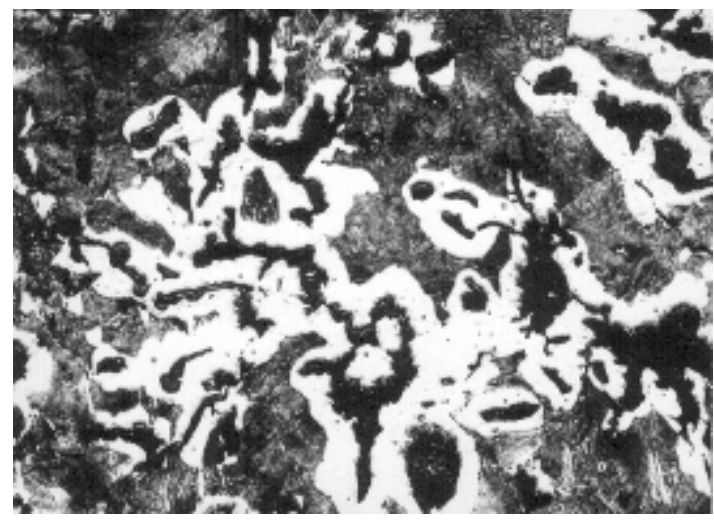

a

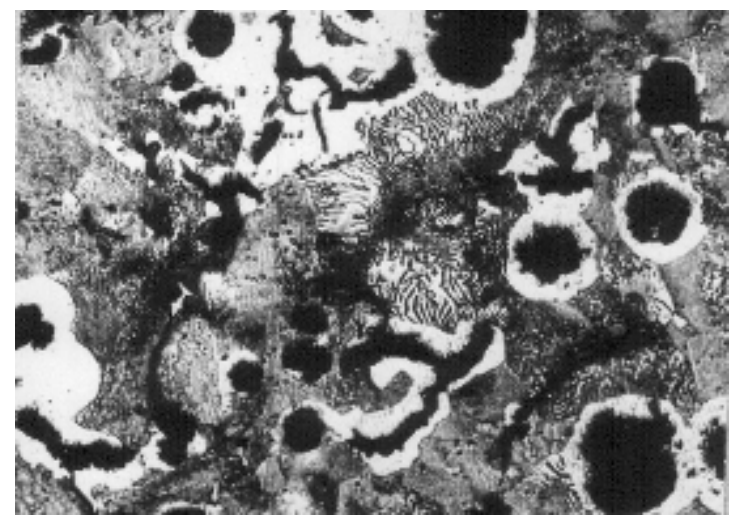

b

Fig. 9. Microstructure of microglaciated chromium CIVG after MICF (cross section of casting with a thickness of $35 \mathrm{~mm}$ ); a-0.25\% Cr;

$\mathrm{b}-\mathbf{0 . 1 5 \%} \mathrm{Cr}, 0.3 \% \mathrm{Cu}, \mathrm{x} 200$ 
The micro alloying additives of chromium can be introduced into the melt and as part of the charge materials. The introduction into the antimony melt, which hastily been used as a pigment fermenter of grey pigments, was investigated both in the composition of the charge materials and in the composition of the modifying mixture. The introduction into the melt with the charge materials of more than $0.01 \% \mathrm{Sb}$ with the content of $\mathrm{Mg}_{\text {res }}$ to $0.02 \%$ and $0.01 \%$ of Ce leads to the complete degeneration of VG in the lamellar. This is especially true for iron-laden modifiers, when the thickness of most graphite inclusions, which are located both in the form of independent colonies, and in the form of processes from the surface of compact and spherical inclusions of graphite does not exceed 1.5 - 2.5 microns (fig. 9). In this case, the content of perlite reaches $90 \%$, which indicates the possibility of efficient use of antimony as a pig iron pearlizer with a low content of magnesium.

Joint introduction of antimony in an amount up to $0.02 \%$ with a ligature at MICF did not cause degeneration of $\mathrm{VG}$ and ensured an increase in the content of perlite in the structure of the metal matrix to $80-85 \%$ (Fig. 10).

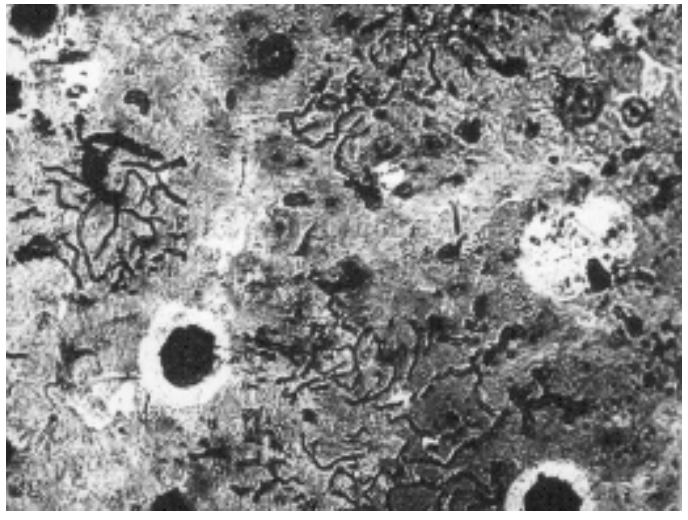

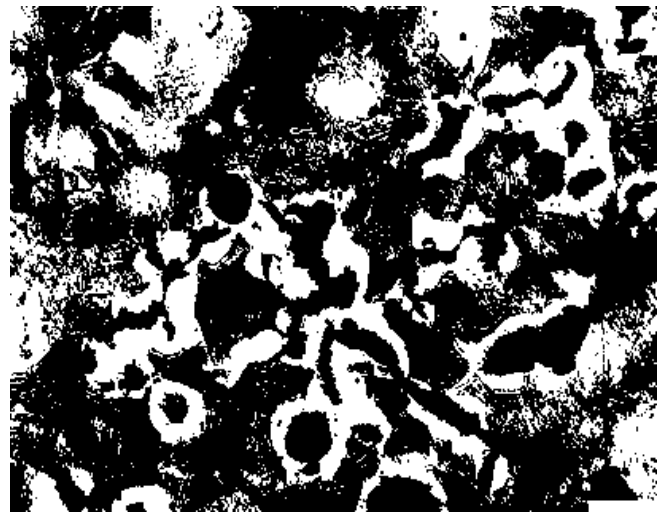

b

Fig. 10. Microstructure of pig-iron, micronutrient $0.015 \%$ antimony. Crossing of $35 \mathrm{~mm}$ thick:

a-Ladle modification;

b-MICF, x200

Ferrite is thus preserved mainly in the form of a shell, around the inclusion of globular graphite. This is due to the lagging of the even distribution in the melt of antimony, which is introduced at MICF, from the process of forming the austenitic membrane around spherical graphite. Increasing the antimony supplementation by more than $0.02 \%$ causes a marked decrease in the compactness of the inclusions of $\mathrm{VG}$, the formation of spiked aphids from the main inclusions of graphite, and at individual sites and before degeneration in the lamellar at the content of perlite to $85 \%$.

In spite of a higher degree of perlization, the hardness of antimony microdermabrasion in all sections of the stepped test is lower than that of cast iron microglaciated with chromium. Particularly significant is the difference in the intersection of a thickness of $5 \mathrm{~mm}$. Measurements of microhardness of structural components of the original pig iron and cast iron, microleaked $\mathrm{Cr}$ and $\mathrm{Sb}$, showed significant differences in the structure of perlite and ferrite.

The micro-ray-spectral analysis of the composition of these structural components shows a significant decrease in the difference between the content of $\mathrm{Si}$ and $\mathrm{Mn}$ in perlite and ferrite fennel CIVG, as well as a decrease in the degree of clearance $\mathrm{Mn}$ do between the eutectic grains. This gives an explanation as a decrease in the propensity to halve the crystallization of the antrious quinine, and to reduce its hardness in comparison with pig-iron, microlagged chromium.

\section{Conclusions}

1. The formation of ferrite sections in CIVG is due to diffusion displacement of carbon atoms. The rate of diffusion of carbon is determined by the rate of cooling of the casting in the process of eutectoid transformation and microlivium in the metal matrix Si, Mn and Cr. Significant branching of the inclusions of vermicular graphite in the volume of the eutectic colony in comparison with spherical graphite, on the one hand, and the formation in the process of crystallization near vermicular graphite of austenitic shell with high content of $\mathrm{Si}$ and low content of $\mathrm{Mn}$ and $\mathrm{Cr}$, on the other, creates favorable conditions for leakage carbon diffusion during eutectic transformation by a stable mechanism.

2. Microalloying of with antimony is a promising technological process of perlizating the metal matrix of different castings with of CIVG of and is building - up wear - resistant cast iron and wares from him.

3. Microalloying of of melt with antimony and chromium in conjunction with of MICF of with 
magnesium ligatures expands the ability to control the structure of the metal matrix of CIVG of in the cast state. It of has been determined that the use of such micronutrients adds up to $85 \%$ to the structure's perlitization. To of achieve a higher degree of perlization of the structure of the metal matrix of CIVG, it is rational to use heat treatment and by a test a friction.

\section{References}

1. Glatush V.A., Doroshenko V.S. Sostoyanie i perspektivyi razvitiya mirovogo ryinka metallootlivok. Oborudovanie i instrument dlya professionalov. 2018. №3. C. 66-70.

2. Dawson S., Schroeder T. Practical Applications for Compacted Graphite Iron. AFS Transactions. 2004. 04. P. 1-9.

3. Zych J., Żyrek A. Vermicular cast iron production in the "Inmold" technology (in the Metalpol casting house) and the assessment of its thermal fatigue resistance. Archives of Foundry Engineering, Polish Academy of Sciences - Katowice: Volume 11. Issue 3. 2011. P. $255-260$.

4. Petrichenco A.M., Solntsev L.A., Kolyada V.A., Zaidenberg A.M. Investigation of the in-mould process and its using in the production of high-strengts iron casting inside faced chill mouls. 45th International Foundry Congress, № 24, p. 3-10.

5. Aulin V.V., Kropivnyi V.M., Kuzyk O.V. Kharakter formoutvorennia hrafitu v chavuni v protsesi vyplavky ta lazernoi obrobky. Visnyk inzh. akademii Ukrainy. 2016. №3. C. 139-145.

6. Salomonsson K., Jarfors A. E. W.Three-Dimensional Microstructural Characterization of Cast Iron Alloysfor Numerical Analyses. Materials Science Forum. 2018. Vol. 925, P. 427-435.

7. Lacaze J., Thébault Y., Freulon A., GuesserW. L. Effect of Cooling Rate on the Eutectoid Transformationin Compacted Graphite Cast Iron. Materials Science Forum Submitted: Switzerland. 2017. Vol. 925, P 12-18.

8. Aulin V.V., Kropivnyi V.M., Kuzyk O.V. Ziasuvannia pryrody protsesiv strukturnykh ta fazovykh peretvoren $\mathrm{v}$ zalizovuhletsevykh splavakh na osnovi utvorennia molekuliarnoi formy vuhletsiu. Zb. nauk. prats KNTU. Tekhnika v s/h vyrobnytstvi, haluzeve mashynobuduvannia, avtomatyzatsiia, vyp. 29. Kirovohrad. 2016. C. $94-104$

9. Roula A., Kosnikov G.A. Manganese distribution and effect on graphite shape in advanced cast irons. Materials Letters 62. 2008. 3796-3799.

10. Thielman T. Zurwirkung von Spurenelementen in GusseisenmitKugelgraphit. Giesssereitechnik. 1970. (1). P. 16-24.

11. Litovka V.I. Povyishenie kachestva vyisokoprochnogo chuguna v otlivkah. Kiev: Naukova Dumka. 1987. 208 c.

12. Gumienny G., Kacprzyk B., Gawroński J. Effect of Copper on the Crystallization Process, Microstructure and Selected Properties of CGI. Archives of Foundry Engineering, Polish Academy of Sciences Katowice, Vol. 17, Issue1. 2017. P. 51-56. 
Аулін В.В., Кропівний В.М., Кузик О.В., Кропівна А.В. Підвищення зносостійкості чавуна спрямованим структуроутворенням його матриці з вермикулярним графітом.

Дослідженню підлягав чавун з вермикулярним графітом марки ЧВГ300-4,для одержання якого, використовували розплави зі складом, близьким до евтектичного, модифікуваного лігатурою VL 63 (M)TC з вмістом $\mathrm{Mg}=6.5 \%, \mathrm{Ca}=1,8 \%, \mathrm{Si}=46 \%, \mathrm{P} 3 \mathrm{M}=0,7 \%, \mathrm{Fe}-$ решта. Наведені результати впливу на структуру металевої матриці умов модифікування та формування вермикулярного графіту. Виявлено перлітні ділянки, розміщені між евтектичними колоніями вермиклярного графіту як місця формування фосфідних включень і мікропор. Визначено, що збільшення дисперсності включень вермикулярного графіту призводить до зниження механічних властивостей за рахунок зниження компактності графітних включень та підвищення феритизації металевої основи. Наведено вплив залишкового вмісту магнію у різних структурах графіту. Досліджено вплив товщини перетину виливка на вміст перліту в структурі металевої матриці чавуну з вермикулярним графітом, зміна їі структури при прискоренні охолодження виливка та характеру розподілу $\mathrm{Si}, \mathrm{Mn}, \mathrm{Cr}$ i Р. Виявлено, що застосування у якості перлітизатора сурьми ускладнює його сильну деглобуляризуючу дію, а хром - відбілюючим впливом. Визначено, що мікролегування хромом забезпечує перлітизацію лише до 60 .. 65 \%, а добавка 0,3\% міді дозволяє підвищити вміст перліту до $80 \%$. Показано, що не зважаючи на більш високий ступінь перлітизації, твердість чавуну з вермикулярним графітом при мікролегуванні сурьмою у всіх перетинах нижча, ніж при мікролегуванні хромом. В той час зниження мікротвердості перліту добавкою сурьми може бути перспективним методом забезпечення підвищеної зносостійкості чавуну 3 вермикулярним графітом.

Ключові слова: вермикулярний графіт, мікролегування, перлітизація, підвищення зносостійкості. 